\title{
The Relationship between Organizational Conduct and National Culture
}

\author{
Ahsan Qamar*, Saqib Muneer, Ahmad Jusoh, Halimah Idris \\ Faculty of Management and Human Resource Development, Universiti Teknologi Malaysia, Johor Malaysia \\ *ahsan_qkhan@yahoo.com
}

\begin{abstract}
This paper puts forwards different existing theories on classifying cultures of different countries. The first theory it introduces is of Hofstede's cultural aspects, then the Hall's Method of classifying culture into low and high context, and lastly the model of cultural differences by Trompenaars. Following that is the discussion on the interaction between organizational behaviour and the national culture. The focus would be the influence of culture on employee motivation, communication, organizational changes and conflict resolution.
\end{abstract}

Keywords: Organizational conduct, National culture, Motivation, Hofstede’s cultural aspects

\section{Introduction}

People living in different parts of the world have different attitudes, behaviours and ways of doing things. For classifying those attitudes and behaviours the concept of culture came into being. Culture is a complicated concept and it can not be defined in simple words. There have been several different researchers who in their own ways tried to explain the definition of culture. One of the earlier researchers in this context was Tylor (1871). His is one of the earliest definitions. He explained culture as a very complex and holistic concept which encompasses all the habits and capabilities that a man acquires being a part of society, which include beliefs, knowledge, morals, art, customs, law and attitudes. Another researcher Herskowits came up with a broader explanation of culture, which was that, all of those things which are not acquired by humans naturally from their environment (Herskowits, 1955). On the basis of his interpretation, the culture may be classified into two categories i.e. objective culture and subjective culture. The examples of objective culture are trains, tables, computers etc., and those of subjective culture are values, norms, roles, etc. There are other descriptions of culture which emerged in the 80's and after. Hofstede (1991) defined culture as the "programming of mind". Whereas Lipicnik (1998) had his belief that direct expression of culture is not easy e.g. like an inclination towards a certain kind of behaviour, but is exhibited in our daily actions, thoughts and attitudes and our relationships to the environment, to ourselves and to the other human beings. Even though there are in excess of 160 different definitions of culture in existence (Kroeber and Kluckhohn, 1985), and among these definitions culture can take on the form, both as a conveyor and receiver of values. It is significant to identify that variations within culture are omnipresent ( $\mathrm{Au}, 1999$; Alvesson, 2002), as well as that variation in culture exists between organizations, regions as well as persons over a period of time. Large amount of prior literature indicates that there exist quite durable differences within different international cultures.

\section{Various Theories on Culture}

There have been several researches and thus resulting in the development of different frameworks for the classification of world cultures (Darlington, 1996). Those frameworks indicate that, for a specific culture what values of people would be. But they have the limitation that their prediction can not encompass all the values of a particular person, as every person in a particular culture has the exact same beliefs and behaviours. At times there is larger variation inside single culture as compared to other cultures.

Hofstede's Cultural Dimensions: Hofstede was focussed on workplace related values in the cultural study he did. The respondents of his study were the IBM employees representing 40 countries of the world. In the analysis of the data which represented employees 116,000 in total, Hofstede was able to extract four distinct dimensions of values regarding the variations across the cultures. Later on he added one more dimension. Even though the original data on which Hofstede based his study, was collected in early seventies, various latest studies from the countries not lying inside Europe, have mostly verified Hofstede's results, with minute additions and subtractions (Chinese Culture Connection, 1987; Darlington, 1996; Hoppe, 1990; Smith, 1996; Trompenaars, 1993). Some major differences have been 
noted when other methods are used or when other than European societies are studied (e.g., Pearce and Osmond, 1999). Hofsted $(1980,1991)$ mentioned that comparison and classification of cultures can be made based on five dimensions that influence behaviour, social practices and organizational practices. Those dimensions are the following:

- Power distance

- Individualism - collectivism

- Masculinity - femininity

- Uncertainty avoidance

- Long term - short term orientation

Power Distance refers to the classes in society or levels/classes in organization. In high power distance cultures, people accept the higher or lower classes in society or an organization or in other words where variations in power and status among people exist and are accepted in the culture (Zenko, 1999). There is a tendency in some of the nations, where differences in authority and power are acceptable among different occupational levels or social classes, yet some other nations do not behave the same way. For instance New Zealand and Sweden are very low in power distance whereas French score relatively high. In Sweden and New Zealand the worker unions are very strong; they make demands on behalf of the employees and possess high influence over work conditions and assignments (Adler, 1991). The French managers keep themselves segregated from the employees, avoid having social interactions with the workers and are not expected to negotiate work duties with them. Individualism-collectivism refers to a tendency or an inclination in organizations as well as societies as a whole. In Individualistic cultures like Spain, Canada or Spain etc., the individual person's needs, concerns and interests are focussed and emphasized over those of their team or organization. It is just the other way around in countries which are collectivist, the examples of which are the Far East countries like Taiwan and Japan. In a society with collectivist values the interaction among the group members is high and the total focus is towards teams and groups. Almost every person is identified with his affiliation with a particular group or team or association, but not so much of a personal identity (Brislin, 1993). The collectivist cultures have hierarchical systems, where some people in authority have the power to control groups of peoples. The Table 1 given below shows some groupings of countries on the basis of power distance and individualism-collectivism

Table 1: Country Groupings based on Hofstede's elements, Power Distance and IndividualismCollectivism (Schermerhorn, Hunt, Osborn, 2000)

\begin{tabular}{lll}
\hline & \multicolumn{1}{c}{ Low Power } & \multicolumn{1}{c}{ High Power } \\
\hline Individualism & New Zealand, Ireland, Germany, Finland, & Belgium, France, Spain, Italy, South \\
& Israel, England, Canada, United States & Africa \\
Collectivism & & Turkey, Columbia, Mexico, Peru, Japan, \\
& & Thailand, Greece, Singapore, Indonesia \\
\hline
\end{tabular}

Uncertainty avoidance is the third dimension of Hofstede, if a particular culture has an association with the uncertainty feature of the future then it is said that the uncertainty avoidance is high for that culture. Those societies have strict rules and regulations and they want to avoid unpredictable situations. Those kinds of cultures avoid taking risks and venture into new ventures. Stability and security are very important characteristics of those cultures, so that they have a preference for an avoidance of conflict, secure life, stable jobs and their tolerance level for deviant persons and ideas is low. If three countries i.e. Japan, USA and Sweden are compared for the level of uncertainty avoidance that they have, Japan has the highest score followed by USA and Sweden. In other words this indicates that the level of tolerance for deviations from standard behavioural practices in Japan is lower than USA and Sweden (Tosi, Mero, Rizzo, 2000).

The dimension of masculinity-femininity for a culture is referred to the extent to which values typically related with masculinity (e.g. dominance and aggressiveness) and femininity (e.g. emotional openness, compassion and empathy) are stressed. Cultures with high masculinity such as Germany, Japan and the USA have comparatively higher ratio of occupational structures based on sex-differentiation, with certain kinds of jobs exclusively assigned to either women or men. Growth, achievement and challenge get a stronger emphasis in jobs (Hofstede, 1991). In masculine cultures people are more aggressive and have more focus on job performance than personal needs and feelings and they are less bothered about the quality of the professional environment. The countries which have higher scores on feminine dimension 
such as Norway and Sweden have the emphasis on employee participation, working conditions and job satisfaction. The last dimension is the long term orientation. This aspect indicates a society's standpoint regarding the future. The western culture has the short-term orientation characteristic, which emphasizes towards the present and may be towards the past, with an orientation towards fulfilling social obligations. On the other hand, long term orientation is a feature of the Asian cultures, which is focussed towards the future; it has belief in saving for the future as well as persistence. Long-term oriented cultures make plans for the long term. Companies invest heavily on training and development of the employees with slow promotions and long term job security.

\section{Cultural Model of Hall}

Edward T. Hall was an American anthropologist who differentiated the communication styles between cultures on the basis of the concept of context. Hall defined context as "the information that surrounds an event; it is inextricably bound up with the meaning of that event" (Hall and Hall, 1995). He classified cultures scaled on high- to low-context. Table 2 mentions some of the examples of countries with communication style ranging in high- or low context.

Table 2: Countries with communication style of High- Or Low-Context

\begin{tabular}{cl}
\hline High-context & \multicolumn{1}{c}{ Low-context } \\
\hline Japan, China, Italy, India, Lebanon, Egypt, Spain & $\begin{array}{l}\text { Germany, Australia, Switzerland, Sweden, } \\
\text { United States }\end{array}$ \\
\hline
\end{tabular}

In a culture with a high context communication style, the main distinguishing feature is that the major part of the information is either internalized in the person or is in the physical context, but only a small part of the message is in explicit, coded and transmitted part. In most of Middle East, for example friends, family, clients and colleagues as part of a large information network have close personal associations. Due to this reason, people who live in high context cultures have a lot of knowledge about others who live in the same networks and extensive background information about the others is not required by them. In these cultures or societies people use different means and modes of communication besides language. Facial expression, timing, tone of voice and behaviour in appropriate ways as are the standard acceptable criteria of their respective society are the tools used for communication. It is the other way around in the low-context cultures where most of the information is expressed explicitly. People in western cultures e.g. Belgium, people have divided their lives into various aspects such as personal lives and work. People do not have enough time to associate more closely to other members in the culture therefore they require receiving detailed information about the other person in case of interaction. These cultures or societies use explicit words to convey the message. The expression through a proper choice of words with complete and accurate meaning is important.

Culture as defined by Trompenaars: Fons Trompenaars developed a framework which is quite useful for the understanding of cultural differences as well as dealing with them. His study investigated through respondents from 47 different countries to come to the conclusion that the variation in national cultures depend on the approaches the members of those societies adopt to solve their problems of three major categories: (1) associations among people, (2) mindsets with respect to time, and (3) attitudes with respect to the environment. According to Trompenaars there are five main cultural differences depending on how people deal with relationships regarding other people, as shown in Table 3, below:

- Universalism versus particularism: "relative emphasis on rules and consistency, or relationships and flexibility".

- Individualism versus collectivism: "relative emphasis on individual freedom and responsibility, or group interests and consensus".

- Neutral versus affective: "relative emphasis on objectivity and detachment, or emotion and expressed feelings".

- Specific versus diffuse: "relative emphasis on focused and narrow involvement, or involvement with the whole person".

- Achievement versus prescription: "relative emphasis on performance-based and earned status, or ascribed status". 
For the problems regarding the attitudes towards time, Fons Trompenaars differentiates among cultures in the perspectives of sequential versus synchronic inclinations. Time is regarded as passing series of events from the sequential point of view, whereas it comprises of interconnected past, present and future from synchronic view.

Table 3: Country groupings based on Trompenaars cultural framework (Schermerhorn, Hunt, Osborn, 2000)

\begin{tabular}{|c|c|c|c|c|c|}
\hline $\begin{array}{l}\text { Universalism } \\
\text { vs } \\
\text { Particularism }\end{array}$ & $\begin{array}{l}\text { Individualism } \\
\text { vs } \\
\text { Collectivism }\end{array}$ & $\begin{array}{l}\text { Neutral } \\
\text { vs } \\
\text { Affective } \\
\end{array}$ & $\begin{array}{l}\text { Specific } \\
\text { vS } \\
\text { Diffuse } \\
\end{array}$ & $\begin{array}{l}\text { Achievement } \\
\text { vs } \\
\text { Ascription }\end{array}$ & $\begin{array}{l}\text { Sequential } \\
\text { vs } \\
\text { Synchronic } \\
\end{array}$ \\
\hline $\begin{array}{l}\text { Canada, USA, } \\
\text { Ireland }\end{array}$ & $\begin{array}{l}\text { USA, Hungary, } \\
\text { Russia }\end{array}$ & $\begin{array}{l}\text { Indonesia, } \\
\text { Germany, } \\
\text { Japan }\end{array}$ & $\begin{array}{l}\text { Spain, Poland, } \\
\text { USA }\end{array}$ & $\begin{array}{l}\text { Australia, } \\
\text { Canada, } \\
\text { Norway }\end{array}$ & $\begin{array}{l}\text { Great Britain, } \\
\text { Belgium, USA }\end{array}$ \\
\hline Vs & Vs & Vs & Vs & Vs & Vs \\
\hline $\begin{array}{l}\text { Indonesia, } \\
\text { China, } \\
\text { Venezuela }\end{array}$ & $\begin{array}{l}\text { Thailand, } \\
\text { Japan, Mexico }\end{array}$ & $\begin{array}{l}\text { Italy, } \\
\text { USA }\end{array}$ & $\begin{array}{l}\text { India, Great } \\
\text { Britain, Egypt }\end{array}$ & $\begin{array}{l}\text { Phillipines, } \\
\text { Pakistan, } \\
\text { Brazil }\end{array}$ & $\begin{array}{l}\text { Malaysia, } \\
\text { Venezuela, } \\
\text { France }\end{array}$ \\
\hline
\end{tabular}

As far as problems regarding the attitudes towards environment, his point of view is that the cultures behave in either outer-directed or inner-directed ways. People belonging to culture with inner directed orientation regard themselves as being detached from nature and have command over it. People from cultures which are outer-directed want to live in harmony with nature, as they consider themselves a part of it.

How Culture Affects the Organizational Behaviour: The advancements in communication technologies have helped the countries to form trade links, thus are getting closer and information regarding other cultures and countries is easily available. Products, no matter where they are manufactured can be marketed and sold anywhere in the world (Vecchio, 2000). At a glance it looks like a homogenized culture all across the world. For example in Slovenia as well as most of the other countries of the world we can find people taking their snack at McDonald's, while clad in Levis jeans, sitting in a Toyota running on petrol from Shell. It seems that probably distinctions among cultures are dying down thus may be a global culture is taking over. On the surface that may be true but if we look deep down then those seemingly universal cultural values appear to be breaking down thus revealing distinctions. For example a McDonald hamburger although available in most countries but is considered trendy and fashionable in Beijing or Moscow, with prices above average, while in New York it may be the cheapest food available. This is because of different perceptions in different cultures. On the macro level i.e. at the country level the cultural differences are evident everywhere. Wars and conflicts are taking place in so many parts of the world. The main purpose of those conflicts at regional level is usually to save some distinct culture. Although culture is not the only significant variable that contributes to differences among nations behaviours. Through recognizing the role played by culture in organizations we would be better able to understand the behaviours across the globe.

\section{How Motivation Differs Across Cultures}

The country and its associated national culture do affect the organizations operating in the country in terms of the motivation of employees. In countries where collectivism gets the cultural preference or in high-context cultures, such as China, giving reward to an individual is against the mindset of people there thus it would be demotivating for the individual as well as the organization and creates no positive motivation. The Masculinity-Femininity dimension of Hofstede creates motivation and demotivation in some situations for nations depending on their cultural standing. For example in a masculine culture, materialistic or status related rewards are appreciated whereas for feminine cultures family time and leisure rewards are preferred. One factor which is important for motivation in all cultures is the work being meaningful. Which indicates the specific characteristic of work that is more significant for the people of a certain culture? Table 4 shows various features of work as well as the significance of each aspect with respect to a selected group of countries. Some countries have the highest preference for the aspect of work being interesting e.g. Belgium, Britain, USA etc. Good pay has the most appreciation for employees in Germany etc. Motivation factors for employees do not only depend upon the culture of the countries to which they belong. For example the specific kinds of rewards that would be desirable would also depend on factors like gender, age, organizational level, education and tenure at work. 
Table 4: Significance of Work Goals (Francesco, Gold, 1998)

\begin{tabular}{|c|c|c|c|c|c|c|c|}
\hline Work goals & Britain & Belgium & Germany & Israel & Japan & Netherland & $\begin{array}{l}\text { United } \\
\text { States }\end{array}$ \\
\hline Interesting work & 1 & 1 & 3 & 1 & 2 & 2 & 1 \\
\hline Good pay & 2 & 2 & 1 & 3 & 5 & 5 & 2 \\
\hline $\begin{array}{l}\text { Good interpersonal } \\
\text { relations }\end{array}$ & 4 & 5 & 4 & 2 & 6 & 7 & 7 \\
\hline Good job security & 3 & 3 & 2 & 10 & 4 & 3 & 3 \\
\hline $\begin{array}{l}\text { A good match } \\
\text { between you and } \\
\text { your job }\end{array}$ & 6 & 8 & 5 & 6 & 1 & 4 & 4 \\
\hline A lot of autonomy & 10 & 4 & 8 & 4 & 3 & 8 & 8 \\
\hline Opportunity to learn & 8 & 7 & 9 & 5 & 7 & 5 & 5 \\
\hline A lot of variety & 7 & 6 & 6 & 11 & 9 & 6 & 6 \\
\hline $\begin{array}{l}\text { Convenient work } \\
\text { hours }\end{array}$ & 5 & 9 & 6 & 7 & 8 & 9 & 9 \\
\hline $\begin{array}{l}\text { Good physical } \\
\text { working conditions }\end{array}$ & 9 & 11 & 11 & 9 & 10 & 11 & 11 \\
\hline $\begin{array}{l}\text { Good opportunity } \\
\text { for promotion }\end{array}$ & 11 & 10 & 10 & 8 & 11 & 10 & 10 \\
\hline
\end{tabular}

As we see in the Table 4 above, Japan and Germany being comparatively low on individualism and high in Masculinity give low priority to "Interesting work", autonomy, match between job and the employee. Whereas the countries standing high on individualism like US, Belgium, Britain and Israel give a higher priority to the three above given dimensions of culture. It is because the cultures high on individualism have their individual needs on priority such as "interesting work and" and work autonomy and they give comparatively less priority to group needs such as interpersonal relations.

How Communication Process is affected by the Culture: It is necessary that people should be extracautious when communicating across the cultures. Whether it is the communication among persons of different subcultures or among different ethnicities within a country or communication between people of different countries. One problem is that of ethnocentrism, which is a tendency when a person gets involved in a cross-cultural communication, then he/she believes that his ethnicity is superior to the others. With this feeling the chances of miscommunication get enhanced by the unwillingness to understand other's point of view. Styles of communication differ across different cultures. Various modes of communication which are in use are the language as well as verbal and nonverbal forms.

Verbal communication is a style of communication where people communicate using words and has two types i.e. direct and indirect. In direct style of verbal communication people select and use those words which have a direct meaning of the message they want to convey, e.g. "No" or "I will do it". But in indirect style people select and use those words which hide the real message e.g. "I will try to do it". People in individualistic countries normally use the direct style and the people in collectivist cultures use indirect style. Nonverbal communication is also a common mode of conveying messages across. It also differs among different cultures and countries. It can be expressed by the expressions on the face e.g. eye contact, gestures and posture. Different cultures interpret the same gestures differently e.g. smile is an indication of being happy or pleased but for some nations it indicates embarrassment (Samovar, Porter, 1991; Hellriegel, Slocum, 2004).

How Culture Impacts Conflict Resolution: How do people sense conflicts is dependent on culture and varies a lot. A theory developed by Stella Ting Toomey regarding the culture and conflict which is based on Hall's high-and-low-context framework (Gundykunst and Ting-Toomey, 1988; Hall, 1976; Hall, Hall, 1995). The culture and conflict theory as mentioned above describes the low-context people as instrumentally oriented. Their view of the world is analytic, they separate people from issues. For people from these cultures, disagreements between people are acceptable, and it should not hurt the relationship between people. Whereas in high-context cultures conflict is not acceptable and usually results in a feeling of insult to one or both parties. There are different reasons of conflicts for low-context and highcontext cultures. For example in low-context cultures conflicts happen because of the violation of one party's expectations by the other. Whereas in high-context cultures it is usually the violation of cultural expectations. Another aspect regarding the conflict situation is about the response of the people involved. 
In low-context cultures the people's response is confrontational, whereas in high-context cultures people involved in conflict situation try to avoid or ignore it. When people from cultures with long-term orientation deal with the people from short-term orientation then the chances of conflict are more. Similar situations are created between the work dealings among individualists and collectivists or between people from cultures of high power distance and low power distance (Schermerhorn, Hunt, Osborn, 2000).

Organizational Change and National Culture: There is a lot of variation among cultures in terms of their willing to change. There are some cultures which have a tendency to change slowly and which create a lot of resistance to change as these cultures are basically traditional. There are other cultures which have a will to change but their progress towards change is hampered by their traditional behaviour so their change is not so fast but faster than the ones mentioned before. The third type of cultures are quite willing to change and they change fast (Treven, 2001). Time orientation in the perspective of change is also an important thing to understand culture (Trompenaars, 1993). There are three types of cultures in the perspective of time orientation. Firstly there are past oriented cultures, for them past events and history is of high importance. These cultures view the present by relating it to the past customs, principles and texts. These types of societies resist change. The other type of cultures is the present oriented culture. For them history as well as future is not important. These do not resist change but their progress is usually slow. Thirdly there are future oriented cultures or societies which have their emphasis on planning and achievements related to future, these are progressive cultures. They want to do for the future generations (Treven, 2003). The resistance to change is also experienced by present and future oriented cultures. The reason being that change is related to uncertainty; it's like stepping into an unknown territory. Sometimes that changes though perceived positive comes out to be negative. That is the reason that every culture whatever is its time orientation would have more or less resistance to change. What is important is that in an organization managers should recognize the sources of resistance so that they could work on them to reduce.

\section{Conclusion}

Since the world is getting more and more interdependent, it is becoming increasingly essential for managers to learn about culture. They have to think beyond the geographical boundaries of the countries they live in, there thinking should be global. Regardless of what the product of their company is or the market they target, eventually one way or the other they would have to face the international competition. Because global competition hits everywhere, be it a small country like Slovenia or a bigger country like Brazil everywhere, the competition from across the geographical borders is there. The other reason why it is important for managers to learn about cultures is due to the fact that their suppliers, competitors, employees or shareholders may belong to other countries with different cultures. With advances in technology the easy movement of men and material across different countries have brought in immigrant workers to other parts of the world. These immigrant workers also bring their native cultures along with them. Therefore to better deal with those immigrant workers it is imperative for the managers to have knowledge about other cultures. As mentioned earlier that the culture has two aspects, one is the global aspect and the other is the multi-domestic aspect. The managers of competitive companies should have thorough knowledge of both aspects so that their respective companies are more effective and competitive on the global stage. Especially they should have a detailed understanding of different cultures of the world as it is then that they would be able to deal effectively with their immigrant employees, their international suppliers and customers as well as competitors.

\section{References}

Alvesson, M. (2002). Understanding Organizational Culture. Sage Publications, London.

Adler, N. J. (1991). International Dimensions of Organizational Behavior, PWS-KENT, Boston.

$\mathrm{Au}, \mathrm{K}$. Y. (1999). Intra-Cultural Variation: Evidence and Implications for International Business, in: Journal of International Business Studies, 30, 799-812.

Brislin, R. (1993). Understanding Culture's Influence on Behavior, Harcourt Brace Jovanovich, Fort Worth.

Chinese Culture Connection. (1987). Chinese Values and the Search for Culture-Free Dimensions of Culture. Journal of Cross-Cultural Psychology, 18, 143-164.

Darlington, G. (1996). Culture: A Theoretical Review, in: P. Joynt and M. Warner (eds.), Managing Across Cultures, International Thomson Business Press, London. 
Gunykunst, W. B. \& Ting-Toomey, S. (1988). Culture and Interpersonal Communication, Sage, Newbury Park, California.

Hall, E. T. (1976). Beyond Culture, Anchor Press, Garden City, New York.

Hall, E. T. \& Hall, M. R. (1995). Key Concepts: Underlying Structures of Culture, in: H.W. Lane, J.J. Di Stefano and M.L. Maznevski: International Management Behavior, Blackwell Publishers, Cambridge, Massachusetts.

Hampden-Turner, C. (1994). Corporate Culture: From Vicious to Virtuous Circles, Piatkus, London.

Hellriegel, D. \& Slocum, Jr., J. W. (2004). Organizational Behavior. Thomson South-Western, Mason, Ohio.

Herskovits, H. J. (1955). Cultural Anthropology, Knopf, New York.

Hofstede, G. (1980). Culture's Consequence, Sage, Newbury Park, California.

Hofstede, G. (1991). Cultures and Organizations, McGraw-Hill, London.

Hoppe, M. H. (1990). A Comparative Study of Country Elites: International Differences in Work-Related Values and Learning and their Implications for Management Training and Develoment, unpublished PhD thesis, University of North Carolina at Chapel Hill.

Kroeber, A. \& Kluckhohn, C. (1985). Culture: A Critical Review of Concepts and Definitions, Random House, New York.

Lipičnik, B. (1998). Ravnanje z ljudmi pri delu, Gospodarski vestnik, Ljubljana.

Pearce, C. L. \& Osmond, C. P. (1999). From Workplace Attitudes and Values to a Global Pattern of Nations: An Application of Latent Class Modeling. Journal of Management, 25, 759-778.

Samovar, L. A. \& Porter, R. E. (1991). Communication between Cultures, Wadsworth, Belmont, California.

Schermerhorn, J. R., Jr., Hunt, J. G. \& Osborn, R. N. (2000). Organizational Behavior, John Wiley \& Sons, New York.

Smith, P. B. (1996). National Cultures and the Values of Organizational Employees: Time for another Look, in: P. Joynt and M. Warner (eds.), Managing Across Cultures, International Thomson Business Press, London.

Tosi, H. L., Mero, N. P. \& Rizzo, J. R. (2000). Managing Organizational Behavior, Blackwell, Cambridge, Massachusetts.

Treven, S. (2001). Mednarodno organizacijsko vedenje, Gospodarski vestnik, Ljubljana.

Treven, S. (2003). The role of culture in organizations, in: Wilby, J. (ed.), Ellen, J.K. (ed.). Proceedings of the 47th Annual Conference of ISSS. July 7-11. Iraklion, Crete, Greece.

Treven, S. (2005). The connection between culture and organizational behavior. In: Program \& Proceedings, (ABR Conference proceedings, Puerto Vallarta, 2005). [Compact disc ed.]. [S.l.: s.n.], 9 pages.

Trompenaars, F. (1993). Riding the Waves of Culture: Understanding Diversity in Global Business, Irwin, New York.

Tylor, E. (1871). Origins of Culture, Harper and Row, New York.

Vecchio, R. P. (2000). Organizational Behavior. The Dryden Press, Forth Worth.

Zenko, Z. (1999). Comparative analysis of management models in Japan, United States of America, and Western Europe: doctoral dissertation, Ekonomsko-poslovna fakulteta, Maribor, Slovenia. 